\begin{tabular}{|l|l|l||}
\hline \multicolumn{2}{|c|}{ PublisherInfo } \\
\hline \hline PublisherName & $:$ & BioMed Central \\
\hline \hline PublisherLocation & $:$ & London \\
\hline \hline PublisherImprintName & $:$ & BioMed Central \\
\hline \hline
\end{tabular}

\title{
Scleroderma exposed
}

\begin{tabular}{|l|l|l||}
\hline \multicolumn{2}{|c|}{ ArticleInfo } \\
\hline \hline ArticleID & $:$ & 4849 \\
\hline \hline ArticleDOI & $:$ & $10.1186 /$ gb-spotlight-20030930-02 \\
\hline \hline ArticleCitationID & $:$ & spotlight-20030930-02 \\
\hline \hline ArticleSequenceNumber & $:$ & 201 \\
\hline \hline ArticleCategory & $:$ & Research news \\
\hline ArticleFirstPage & $:$ & 1 \\
\hline \hline ArticleLastPage & $:$ & 2 \\
\hline \hline & & RegistrationDate : 2003-9-30 \\
\hline ArticleHistory & $:$ & OnlineDate \\
\hline \hline ArticleCopyright & $:$ & BioMed Central Ltd2003-9-30 \\
\hline \hline ArticleGrants & $:$ & \\
\hline \hline ArticleContext & $:$ & 130594411 \\
\hline \hline
\end{tabular}




\section{Cathy Holding}

Email: cholding@hgmp.mrc.ac.uk

Comparison of gene expression profiles using microarray analysis of tissues from patients suffering from systemic scleroderma and of those from unaffected individuals is reported in the September 29, 2003 Proc Natl Acad Sci USA by Michael Whitfield and colleagues at University of California at San Francisco. Results provide the possibility of a means of identifying affected individuals before symptoms appear and of early treatment to prevent the disease becoming sufficiently advanced to threaten the life of the patient (Proc Natl Acad Sci USA 2003, DOI:/10.1073/pnas.1635114100).

Whitfield et al. prepared total RNA from punch biopsies from four affected and four unaffected individuals taken from the forearm - diseased in the affected group - and the back. Analysis was carried out on Affymetrix oligonucleotide arrays representing 12,000 human genes and analyzed by hierarchical clustering. The authors identified 2776 differentially expressed genes, readily determining diseased from normal tissues. Normal back tissue in affected individuals gave the same profile of gene expression as the diseased tissue from the arm, suggesting the means for early detection of the disease could be normal tissue.

Gene expression profiles in cell lines derived from tissues constituting normal skin provided explanation for the observed expression profiles. Fibroblast cell lines outgrown from the biopsies failed to give differential gene expression profiles, precluding their use for diagnostic purposes. An expression profile similar to B lymphocytes suggested the involvement of this inflammatory cell type where previously only $\mathrm{T}$ cells were thought to be present, providing a new direction for research into the disease. In addition, several potential diagnostic disease markers were identified.

"This approach has the advantage of identifying multiple genes representing multiple different cell types in a complex disease whose underlying pathogenesis is still unknown. From a research perspective, it may give rise to new hypotheses about pathogenesis that can be tested," the authors conclude.

\section{References}

1. Systemic sclerosis-scleroderma

2. Proceedings of the National Academy of Sciences USA, [http://www.pnas.org/]

3. University of California at San Francisco, [http://www.ucsf.edu/]

This PDF file was created after publication. 